INTIQAD: JURNAL AGAMA DAN PENDIDIKAN ISLAM

ISSN 1979-9950 (print) || ISSN 2598-0033 (online), http://jurnal.umsu.ac.id/index.php/intiqad DOI: 10.30596/intiqad.v13i2.7481

Vol. 13, No. 2 (December 2021)

\title{
Integrasi Technological Pedagogical Content Knowledge (TPACK) Dengan Information Communation and Technology (ICT) Pada Masa Pandemi Covid 19 di SMA Gema 45 Surabaya
}

\author{
Fifin Dayanti $^{1 *}$ Abdulloh Hamid $^{2}$ \\ Universitas Islam Negri Sunan Ampel Surabaya*1,2 \\ "1 email: fifindayanti007@gmail.com \\ ${ }^{2}$ email: doelhamid@uinsby.ac.id
}

\begin{abstract}
Technological developments in the digital world in this millennial era have an impact on the continued development of learning models in educational institutions, one of the learning models that can be an alternative is TPACK integrating learning with digital computer technology so that students are expected to be more innovative and in carrying out the learning process during the covid pandemic. 19. This research method uses qualitative methods with data collection techniques through interviews, observation and documentation. In the $21 \mathrm{st}$ century, teachers need to understand and have Technological Pedagogical Content Knowledge (TPACK) competencies. TPACK is a theoretical framework for designing learning models by integrating three main aspects, namely technology, pedagogy, and content. This model has three equally important intersections, namely the intersection between bodies of knowledge expressed as PCK (pedagogical content knowledge), TCK (technological content knowledge), TPK (technological pedagogical knowledge), and TPACK (technology, pedagogy, and content knowledge).
\end{abstract}

\section{Keywords: $\quad$ TPACK, Educational Technology, Pandemic Covid 19.}

\begin{tabular}{l}
\hline Abstrak \\
\hline Perkembangan teknologi dalam dunia digital pada era \\
milenial ini berdampak pada terus berkembangnya model \\
pembelajaran pada lembaga pendidikan, salah satu model \\
pembelajaran yang bisa menjadi alternatif adalah TPACK \\
mengintegrasikan antara pembelajaran dengan teknologi \\
digital komputer sehingga diharapkan siswa lebih inovatif \\
dalam melaksanakan proses pembelajaran pada masa \\
pandemi covid 19. Metode penelitian ini menggunakan \\
\hline \hline
\end{tabular}


metode kualitatif dengan teknik pengumpulan data melalui wawancara, observasi dan dokumentasi. Pada abad 21 guru perlu memahami dan mimiliki kompetensi Technological Pedagogical Content Knowledge (TPACK). TPACK adalah kerangka kerja/kerangka teoritis untuk mendesain model pembelajaran dengan mengintegrasikan tiga aspek utama yaitu teknologi, pedagogi, dan content. Model ini memiliki tiga interseksi yang sama penting yaitu interaksi antara badan pengetahuan yang dinyatakan sebagai PCK (pedagogical content knowledge), TCK (technological content knowledge), TPK (technological pedagogical knowledge), and TPACK (technology, pedagogy, and content knowledge)

\section{Kata Kunci : TPACK, Teknologi Pendidikan, Pandemi} Covid 19.

\section{A. Pendahuluan}

Abad 21 sekarang ini sangatlah menuntut manusia untuk menggunakan teknologi agar tidak ketinggalan berbagai informasi dan hal-hal penting lainnya. Apalagi di dalam dunia pendidikan. Seorang pendidik harus mampu mengintegrasikan teknologi ke dalam strategi pembelajaran agar pembelajaran yang dilakukan secara daring tetap mampu menjadi sarana tercapainya tujuan sebuah pembelajaran.

Kebijakan pemerintah dalam menghadapi wadah pandemi virus corona 19 telah memaksa pemberlakuan Social Distancing dalam semua aspek termasuk pendidikan. Itulah yang kemudian menjadi dasar dilaksanakannya pendidikan jarak jauh atau lebih dikenal dengan istilah Belajar dari Rumah (BDR). Keadaan ini memaksa segenap stakeholder pendidikan untuk menerapkan berbagai metode yang tepat dalam melaksanakan proses pembelajaran sehingga tujuan pembelajaran tetap terlaksana meskipun dalam keadaan yang berbeda.

Dijelaskan juga bahwasanya pengintegrasian teknologi ke dalam sebuah sistem pembelajaran di masa pandemi ini mampu memenuhi kebutuhan pendidik dan peserta didik. Salah satunya yaitu memudahkan pendidik untuk merencanakan hingga mengevaluasi sistem pembelajaran yang dilakukan secara daring (Khotimah, dkk, 2020) 
INTIQAD: JURNAL AGAMA DAN PENDIDIKAN ISLAM

ISSN 1979-9950 (print) || ISSN 2598-0033 (online), http://jurnal.umsu.ac.id/index.php/intiqad

DOI: $10.30596 /$ intiqad.v13i2.7481

Vol. 13, No. 2 (December 2021)

Semisal seorang guru PAI yang mengajarkan kepada siswa-siswinya agar mampu menjalankan perintah Allah SWT dan menjauhi larangannya beserta ajaran-ajaran lainnya, hal ini belum mampu tersampaikan dengan baik, dikarenakan siswa belum mampu memahami dengan sempurna arti dari sebuah materi yang diajarkan guru PAI tersebut. Yang mana hal ini disebabkan oleh minimnya metodelogi, strategi dan inovasi dalam pembelajaran sehingga materi PAI sendiri menjadi bahan yang kurang menarik bagi sebagian besar siswa.

Proses pembelajaran yang diterapkan dalam sebuah lembaga pendidikan akan menunjukkan seberapa baik dalam mengikuti kemajuan dan pekembangan teknologi sehingga lembaga pendidikan tersebut mampu menjadi transformasi dalam dunia pendidikan. dengan demikian maka dapat dikatakan bahwasanya mengintegrasikan teknologi ke dalam sebuah proses pembelajaran menjadi suatu hal yang wajib. Semua lembaga akan berlomba-lomba dalam mengembangkan penggunaan teknologi pendidikan terutama di SMA GEMA 45 Surabaya. Penilitian ini dilakukan di
SMA GEMA 45 Surabaya. Dalam proses pembelajaran, setiap guru memiliki karakteristik dan pemahaman yang berbeda dalam mengaplikasikan kompetensi yang mereka kuasai, sehingga terkadang ada guru yang masih menggunakan model pembelajaran yang monoton.

Proses belajar mengajar sangat dipengaruhi oleh bagaimana tingkat kemampuan dan literasi yang dimiliki oleh peserta didik. Kemampuan literasi meliputi kecakapan dalam berkomunikasi tidak hanya dalam cakupan itu tapi juga dalam hal menulis. Selain itu, literasi memiliki makna yang lebih luas seperti bagaimana cara berkomunikasi seseorang, dan bagaimana berinteraksi dalam kehidupan masyarakat (Lutvaidah, 2016). Oleh sebab itu agar sebuah tujuan pembelajaran tercapai sudah menjadi keharusan bagi setiap guru untuk pintar dan bijaksana dalam menentukan strategi dengan cermat dan saksama (Farikhah, 2015) agar tujuan pembelajaran bisa tercapai dengan baik.

Perkembangan teknologi dan internet pada era digitalisasi saat ini sangat pesat. Dampaknya, seiring dengan terus berkembangnya teknologi 
menghadirkan perubahan rancangan dan pembaharuan pengertian literasi. Kegiatan literasi sangat identik dengan kegiatan membaca dan menulis, tetapi dapat dimaknai lebih luas sebagai keterampilan dan kemampun untuk memanfaatkan informasi dan pengetahuan yang dimiliki seseorang yang sebelumnya sudah diterima, baik berbentuk tulisan, gambar, dan tayangan. Guru PAI diharapkan dapat mencari solusi atau salah satu cara agar peserta didik tak akan mudah bosan untuk mengikuti pelajaran Pendidikan Agama Islam (Faradila, Aimah, 2018).

Model TPACK merupakan satu dari sekian model pembelajaran yang digambarkan memiliki empat tingkatan dalam pendekatannya pada teknologi yang akan digunakan (Niswati, Zainiyati, 2020). TPACK model ini merupakan sebuah pendekatan yang dijadikan landasan pola pembelajaran konvensional menjadi berbasis teknologi (Burbules, dkk, 2020), oleh karena itu menarik untuk diteliti bagaimana cara TPACK model ini bisa diterapkan dalam pembelajaran jarak jauh dimasa pandemi.

Menggabungkan inovasi, metode pembelajaran, dan materi pertunjukan adalah sesuatu yang penting untuk diterapkan. Ini secara tegas diidentifikasi dengan struktur TPACK Teknologi, Pedagogis, Konten, Pengetahuan (Koehler, dkk, 2013). Kombinasi TPACK membantu dalam pelaksanaan pembelajaran internet (Kohler, dkk, 2013). Sesuai dengan ini, Pinkley menambahkan bahwa dalam kehidupan di seluruh dunia di mana inovasi telah menjadi bagian tak terpisahkan dari kehidupan sehari-hari, biasanya semakin banyak individu yang memanfaatkan inovasi untuk kebutuhan individu dan ahli. (Pinkley, 2010) Meskipun demikian, pendidik dalam menyelesaikan pembelajaran berbasis web pada umumnya akan menghadirkan pembelajaran berbasis web melalui aplikasi.

Para pendidik belum memasukkan metode pembelajaran dan bahan ajar. Hal ini disampaikan Drajati bahwa pengajar belum mengkoordinir TPACK dalam pembelajaran berbasis web. Sehingga siswa belum secara efektif dikaitkan dengan pembelajaran dan umumnya akan merasa lelah dan tampak mengabaikan materi yang diberikan oleh instruktur (Drajati, 2020). Pendidik bahasa Inggris menangani masalah yang 
INTIQAD: JURNAL AGAMA DAN PENDIDIKAN ISLAM

ISSN 1979-9950 (print) || ISSN 2598-0033 (online), http://jurnal.umsu.ac.id/index.php/intiqad

DOI: 10.30596/intiqad.v13i2.7481

Vol. 13, No. 2 (December 2021)

diidentifikasi dengan campuran

pemanfaatan inovasi, metode pengajaran dalam pembelajaran. Jadi secara umum RPP belum tergabung dengan ini. Kemampuan instruktur bahasa Inggris dalam menambah rekonsiliasi TPACK sangat penting mengingat sirkulasi pembelajaran yang tidak memihak membutuhkan pemanfaatan inovasi. Jadi penting untuk mengarahkan penggabungan TPACK untuk mempersiapkan instruktur.

\section{B. Metode Penelitian}

Dalam penelitian ini, peneliti menggunakan metode penelitian deskriptif dan metode kualitatif. Gunakan observasi, kuesioner, wawancara dan dokumen untuk mengumpulkan data. Teknologi observasi dilakukan dengan menggunakan observasi partisipatif, dan peneliti akan langsung mengikuti pembelajaran di kelas. Observasi ini melibatkan partisipasi peneliti dalam individu atau komunitas yang diamati. Kemudian muncul kuesioner, peneliti memberikan beberapa pernyataan kepada responden untuk dijawab. Selain itu, pengumpulan data melalui wawancara dilakukan secara tatap muka.

Penelitian ini menggunakan interview yang tidak terstruktur, untuk situasi ini peneliti tidak menggunakan pembicaraan dengan aturan yang telah sengaja diatur sebelumnya. Yang digunakan dalam panduan interview adalah tata letak masalah. dokumentasi yang dimaksud dalam penelitian ini adalah dokumentasi sebagai foto atau rekaman yang menggambarkan interaksi eksplorasi yang terjadi. Titik fokus dari eksplorasi ini adalah Implementasi TPACK model dalam Pembelajaran Jarak jauh Pendidikan Agama Islam pada Masa Pandemi. Peneliti melakukan penelitian ini di SMA GEMA 45 Surabaya.

Peneliti berusaha membandingkan dua kelompok, yaitu guru SMA dan guru SMK laki-laki dan perempuan. Pengambilan sampel diambil dengan teknik kelompok. Jikalau sebuah sampel yang ada merupakan bagian dalam pengelompokan tersebut, maka yang tepat untuk digunakan adalah teknik clustering (Punaji Setyosari, 2016). Cara penentuan sampel yang diambil didasarkan pada wilayah. 
Jumlah sampel yang dikumpulkan peneliti tergantung dari kesediaan guru mengisi alat TPACK yang diadopsi dari jurnal Srisawasdi dan mengisi data biometrik peserta. Selain itu, peneliti mewawancarai partisipan sebelum membagikan instrumen.

Setelah mendapatkan data, peneliti mengelompokkan data sesuai dengan konsep yang dikemukakan partisipan secara garis besar pada setiap partisipan. Kemudian di kategorikan berdasarkan durasi pengalaman mengajar masingmasing partisipan. Selanjutnya mengkategorikannya ke dalam tujuh komponen TPACK yang terbagi dalam beberapa kategori.

\section{Hasil dan Pembahasan \\ 1. Peran integarsi TPACK dalam pembelajaran daring}

Persiapan tersebut memberikan pengetahuan dan pemahaman baru kepada instruktur dalam menyelesaikan pembelajaran internet. Koordinasi metode pembelajaran yang lepas dari pemanfaatan inovasi dihadirkan sebagai ciri rekonsiliasi TPACK.

Metode instruksional ini membantu pendidik dengan memiliki gambaran yang jelas terkait dengan rencana pendidikan online. Dengan tujuan agar instruktur dapat membuat rencana latihan pembelajaran internet dengan mengoordinasikan inovasi, metode pembelajaran, dan materi ajar. Instruktur juga memperoleh pengetahuan ke dalam TPACK dalam latihan pembelajaran berbasis web.

Aksesibilitas panggung gratis yang mendukung pembelajaran membantu instruktur sebagai perangkat pembelajaran internet. Perangkat ini mungkin dapat menonjol bagi siswa dalam pembelajaran berbasis web. Kewajaran dan kegunaan panggung juga dapat mencakup siswa secara bersamaan.

2. Metode yang paling efektif untuk Mengukur Technological Pedagocal Content Knowledge

Pendidik dapat disurvei pada lima level unik menggunakan model siklus pilihan inventif (Roger, 2012) mencirikan level-level ini sebagai berikut:

a. Recognizing (pengetahuan), ketika pengajar dapat memanfaatkan inovasi/TIK dan melihat susunan inovasi/TIK dengan konten namun tidak mengoordinasikan inovasi dalam pembelajarannya. 
b. Accepting (persuasi), ketika instruktur membentuk mentalitas besar atau negatif terhadap konten pembelajaran dengan inovasi yang tepat.

c. Adapting (keputusan), ketika pendidik disibukkan dengan latihan-latihan yang langsung mengambil keputusan untuk menerima atau menolak mempelajari IPA dengan inovasi/TIK yang sesuai.

d. Exploring (implementasi), ketika pengajar secara efektif mengkoordinir pembelajaran IPA dengan menyesuaikan inovasi/TIK.

e. Advancing (konfirmasi), ketika pendidik menilai konsekuensi dari penentuan pilihan tentang koordinasi pembelajaran sains dengan inovasi yang sesuai.

TPACK adalah sebuah model pembelajaran yang memiliki empat tahap Substitution, Augmentation, Modification dan Redefinition (Rusydiyah, 2019). Langkah awal yang peneliti lakukan sebelum meniliti tentang implementasi TPACK pada sebuah mata pelajaran, maka dilakukan pemetaan minat peserta didik terlebih dahulu untuk mengetahui seberapa besar minat terhadap mata pelajaran tersebut.

Salah satu tujuan dalam pengimplementasian TPACK model dalam pembelajaran adalah adanya perubahan dalam metode yang digunakan dalam pembelajaran dari cara tradisional menjadi teknologi informasi dengan menambahkan kemampuan baru untuk menunjang dan mengoptimalkan fungsi dari aplikasi tersebut. Penggunaan aplikasi digital selalu berkembang sesuai dengan perkembangan zaman, sehingga dengan memanfaatkan aplikasi digital ini dapat meningkatkan hasil pemahaman siswa.

Manfaat dalam penggunaan dan penerapan model pembelajaran TPACK adalah dengan terintegrasinya dengan teknologi komputer sehingga mampu menciptakan pembelajaran yang inovatif dan lebih mudah disesuaikan dengan perkembangan teknologi yang ada. Model pembelajaran ini sangat terbantu penerapannya dengan adanya teknologi digital. Salah satu manfaat dalam pembelajaran dengan mengoptimalkan penggunaan teknologi digital dengan komputer adalah dengan adanya interaksi dengan guru dan dunia luas, sehingga peserta didik memiliki 
INTIQAD: JURNAL AGAMA DAN PENDIDIKAN ISLAM

ISSN 1979-9950 (print) || ISSN 2598-0033 (online), http://jurnal.umsu.ac.id/index.php/intiqad

DOI: 10.30596/intiqad.v13i2.7481

Vol. 13, No. 2 (December 2021)

kesempatan untuk mengeksplorasi sendiri untuk menunjang pemahaman mereka dalam pembelajaran.

Selain memiliki kelebihankelebihan dalam memudahkan proses pembelajaran, model pembelajaran TPACK ini juga memiliki kelemahan diantaranya adalah kenyaataan bahwa tidak setiap lembaga pendidikan memiliki sarana dan prasaana pelengkap seperti komputer yang memutuhkan biaya besar dan relatif mahal, selain itu diperlukan keahlian khusus untuk menggunakan dan mengembangkan media tersebut (Namiroh, dkk, 2018). Berdasarkan hasil penelitian ini ditemukan bahwa tidak semua siswa di SMA GEMA 45 Surabaya sudah mampu mengoperasikan IT dengan baik, sehingga peran pendampingan guru sangat dibutuhkan.

Penggunaan TPACK model yang teritegrasi dengan teknologi digital ini juga menuai kritik diantaranya adalah dikatakan bahwa TPACK model ini mengabaikan Konteks (Hamilton, dkk, 2016). Penggunaan TPACK model ini juga dinilai rigid dan hirarkis yaitu menganggap bahwa Dengan penerapan model TPACK (seperti taksonomi), orang telah belajar bahwa jika guru menggunakan teknologi dalam memodifikasi atau mendefinisikan ulang level daripada mengganti atau meningkatkan level, mereka akan dapat menggunakan teknologi secara lebih efektif untuk pembelajaran. TPACK model juga dianggap lebih mengutamakan hasil daripada proses, yang lebih mengutamakan integrasi dengan teknologi yang objeknya adalah yaitu yang menggunakan model tersebut bukan pada proses belajar mengajar peserta didik.

TPACK model masih membutuhkan penelitian dan riset lebih lanjut karena dengan bukti- bukti yang lebih kongkrit karena sampai saat ini sumber dari model hanyalah sebuah blog yang berisi slide- slide presentasi yang disampaikan oleh Ruben R. Puentedura pada pelatihan dan simposium. Model ini juga dinilai sangat teknosentrik karena hanya fokus penilain intensitas dan transformatifnya proses pembelajaran dengan integrasi teknologi digital, Kenyataannya, tujuan pembelajaran hanya dapat dicapai dalam dua tahap pertama, dan tidak perlu memodifikasi atau mendefinisikan ulang tahap tersebut. 
Berdasarkan kritik pada model ini diatas, dapat disimpulkan bahwa TPACK model bukanlah satu-satunya model yang dapat kita gunakan dalam melakukan inovasi dalam pembelajaran. Tetapi dapat menjadi alternatif dalam mengembangkan pembelajaran yang teringtegrasi dengan teknologi dimasa pandemi seperti yang terjadi sekarang.

Selanjutnya pemanfaatan aset pembelajaran yang dimanfaatkan oleh pendidik masih terbatas pada bahan bacaan biasa, belum memanfaatkan aset online berbasis inovasi. Januszewski dan Molenda mengklarifikasi bahwa aset pembelajaran secara keseluruhan mendukung latihan pembelajaran, termasuk jaringan dan materi yang mendukung secara emosional, hanya sebagai iklim pembelajaran yang dapat digunakan untuk bekerja dengan latihan pembelajaran dan mengembangkan pelaksanaan pembelajaran lebih lanjut. (Januszewski, Molenda, 2008). Secara umum kewajaran aset pembelajaran dan media pembelajaran dapat bekerja dengan pemahaman siswa terhadap materi pembelajaran. Aset pembelajaran yang dimanfaatkan oleh pendidik masih terbebani dengan pemanfaatan buku pegangan siswa. Pemanfaatan buku pegangan siswa belum memiliki pilihan untuk meningkatkan pelaksanaan pembelajaran dengan metodologi atau teknik pembelajaran yang digunakan oleh pengajar. Akibatnya, pendidik belum ideal dalam memilih sumber/media pembelajaran yang sesuai dengan pendekatan/strategi yang dipilih

Berdasarkan gambaran di atas, dapat disimpulkan bahwa otoritas pendidik terhadap TCK perlu ditingkatkan, khususnya dalam hal penerapan inovasi dalam pembelajaran. Pemanfaatan inovasi dalam pembelajaran dapat memperluas inspirasi belajar siswa, menjadikan pembelajaran lebih menyenangkan, memberikan lebih banyak informasi kepada siswa, bekerja dengan pertukaran data yang mendukung pembelajaran, siswa dinamis dalam belajar, pelaksanaan pembelajaran menjadi lebih produktif memanfaatkan inovasi data dalam pembelajaran bahasa dan menulis. reaksi positif (Husaini, 2014) (Sari, 2015). Terlebih lagi, pelatihan di masa transformasi modern 4.0 meminta rekonsiliasi inovasi data. 


\section{Simpulan}

Penggunaan teknologi komputer dalam pembelajaran merupakan inovasi dalam pembelajaran yang dalam pengimplementasiannya menggunakan TPACK model ini memiliki nilai pengalaman yang berbeda terhadap peserta didik, model ini merupakan model alternatif yang bisa digunakan dalam pembelajaran pada masa pandemi ini. TPACK model ini memiliki kesamaan dengan taksonomi bloom yang menggunakan anak tangga.

Pembelajaran TPACK model ini memberikan warna yang berbeda dari model-model pembelajaran yang telah ada, terintegrasinya dengan teknologi komputer sangat terlihat adanya perubahan cara lama dalam dunia pendidikan, sehingga model ini mampu mengubah pembelajaran konvensional menjadi lebih modern.

Berbagai manfaat dalam penggunaan model pembelajaran TPACK ini telah memberikan banyak dampak positif dalam proses pembelajaran para siswa. Dimana siswa disini juga memperoleh kemampuan penggunaan model baru dengan kombinasi teknologi dalam TPACK. Pada akhirnya semua model pembelajaran yang digunakan sematamata dengan maksud untuk meningkatkan hasil belajar siswa. Sehingga diperlukan pula pengawasan dan penerapan model TPACK yang sesuai dengan tujuan pencetus model TPACK itu sendiri.

\section{E. Daftar Pustaka}

Ashcroft, Robert J, and Andrew C Imrie. (2014). "Learning Vocabulary with Digital Flashcards." In JALT2013 Conference Proceedings, 639-45.

Faradila, Shafira Puspa, and Siti Aimah. (2018). "Analisis Penggunaan Media Pembelajaran Untuk Meningkatkan Minat Belajar Siswa Di SMA N 15 Semarang." In Prosiding Seminar Nasional Mahasiswa Unimus. Vol. 1.

Farikhah, Siti. (2015). "Manajemen Lembaga Pendidikan." Aswaja Presindo.

Hamilton, Erica R, Joshua M Rosenberg, and Mete Akcaoglu. (2016). "The Substitution Augmentation Modification Redefinition (SAMR) Model: A Critical Review and Suggestions for Its Use." TechTrends 60, no. 5: 433-41.

Lobo, Alejandra Giangiulio, and Rocío Lara Jiménez. (2017). "Evaluating Basic Grammar 
INTIQAD: JURNAL AGAMA DAN PENDIDIKAN ISLAM

ISSN 1979-9950 (print) || ISSN 2598-0033 (online), http://jurnal.umsu.ac.id/index.php/intiqad DOI: 10.30596/intiqad.v13i2.7481

Vol. 13, No. 2 (December 2021)

Projects, Using the SAMR

Model.” Letras, no. 61: 123-51.

Lutvaidah, Ukti. (2016). "Pengaruh Metode Dan Pendekatan Pembelajaran Terhadap Penguasaan Konsep Matematika." Formatif: Jurnal Ilmiah Pendidikan MIPA 5, no. 3.

Namiroh, Siti, Mohamad Syarif Sumantri, and Robinson Situmorang. (2018). "Peran Multimedia Dalam Pembelajaran." In Prosiding Seminar dan Diskusi Pendidikan Dasar.

Niswatin, Khoirun, and Husniyatus Salamah Zainiyati. (2020). "Implementasi Model SAMR (Substitution, Augmentation, Modification , Redefinition) di MI Al-Ishlah Glagah Lamongan." Pendidikan Islam 15.

Rusydiyah, Evi Fatimatur. (2019).

Teknologi Pembelajaran

Implementasi Pembelajaran Era
4.0. Surabaya: UIN Sunan Ampel Press.

Wibawanto, Hari. (2019). "Model Evaluasi Integrasi TIK dalam Pembelajaran." In Prosiding Seminar Nasional Pendidikan Matematika II (SNPMAT II): Pembelajaran Matematika Dalam Era Revolusi Industri 4.0, 12. Universitas Halu Oleo Press.

Wulandari, M, and M E Harendita. n.d. "Are We Ready yet to Flip Our Classes." Analysis on Students' and Lecturers' Use of Technology, 219-39.

Basit Abdulloh Khotimah Husnul, Zainiyati Husniyatus Salamah, Hamid Abdulloh. (2020). “Aplikasi E-Learning Madrasah Solusi Pembelajaran Online di Tengah Pandemi Covid-19 di Ma Negeri Insan Cendikia, Kendari, 107-114. 